\title{
The Role of the Qods Force in the Foreign Policy of the Islamic Republic of Iran
}

\author{
Ardavan Khoshnood
}

The establishment of the Islamic Republic of Iran (IRI) in I979 had a great impact on the question of security in both the region and outside of the Middle East. The foreign policy of the new republic would show hostility and aggression as terrorism became its modus operandi. In order to safeguard the newly established regime and the revolution, the Islamic Revolutionary Guard Corps (Pasdaran) was established, of which its external branch was named the Qods Force (QF). By reviewing scholarly works and regime publications, the current article aims to study and analyze the foreign policy of the IRI and the role of the QF in it. As the IRI is today deemed to be a sponsor of terrorism, and as the tensions between the IRI and the United States have increased since the Pasdaran and its QF was designated a terrorist organization, the role of the QF in the foreign policy of the IRI is even more important. This article shows that even though terrorism through the QF is still the modus operandi of the IRI, the QF has through the years evolved and uses other methods in order to influence and cement the power of the IRI in the international arena. The article also concludes that it is highly unlikely for the IRI to be reformed as long as the current leadership and establishment continue to rule, and if the regime feels threatened, it will almost certainly use terrorism and violence in order to guarantee its survival.

Ardavan Khoshnood. The Role of the Qods Force in the Foreign Policy of the Islamic Republic of Iran. Central European Journal of International and Security Studies I4, no. 3: 4-33.

(C) 2020 CEJISS. Article is distributed under Open Access licence: Attribution NonCommercial 3.0 Unported (cc by-nc 3.0). 
Keywords: Iran, terrorism, political violence, Qods Force, Islamic Revolutionary Guard Corps

After the establishment of the Islamic Republic of Iran (IRI) in I979, Islam became the de facto source of legitimacy for the newly born re-

public, affecting all parts of society. ${ }^{\mathrm{I}}$ The new regime's interpretation Ardavan of Islam was allowed to guide their foreign policy, permitting measures such as threat and use of violence to bring forth their objectives. ${ }^{2}$ Today, at the heart of Iran's foreign policy, lies the military organization Pasdaran ${ }^{3}$ and its Qods ${ }^{4}$ Force (QF) which is responsible for foreign operations.

In recent years, the Pasdaran and the QF have gained more influence and power in Iran and its foreign policy. The QF is therefore not unsurprisingly deemed to be a national security threat for many countries in the region ${ }^{5}$, Western Europe ${ }^{6}$ as well as the American continent 7 . Because of this, the Trump administration in April 2org designated the Pasdaran and thus the QF as a terrorist organization ${ }^{8}$, and on 3 January 2020, assassinated the commander of the QF, Qasem Soleimani.

As Iran continues to be an important player in the Middle East, at the same time aspiring for more influence in Western Europe (WE) and the American continent, in line with the foreign policy of the IRI, it is important to study and analyze the foreign policy of Iran and the role of the $\mathrm{QF}$ in it.

\section{Pasdaran}

Pasdaran was de facto established in late April $1979^{\circ}$, and de jure recognized on 5 May I979, after a decree issued by Ruhollah Khomeini ${ }^{10}$. The founding members of the Pasdaran already knew each other from secret Islamic military camps in Lebanon and Syria, which were set up in order to train opponents of the Shah. ${ }^{\text {II }}$

After the victory of the Islamic revolution in Iran, loyalists to Khomeini organized themselves in revolutionary committees to manage security in different cities of the country. It was a need of organizing these committees in which the idea of the Pasdaran was born. Khomeini, fearful of the military still being loyal to the Shah, saw also an opportunity in the Pasdaran to create a parallel military organization loyal to him which also could defend the revolution from domestic and foreign threats. His distrust of the regular army grew even stronger when members of the army and a great number of civilians still loyal 
to the Shah tried to kill Khomeini and overthrow ${ }^{12}$ the Islamic republic in July $1980 .{ }^{13}$

Initially responsible for protecting the newly established IRI and the borders of the country, Pasdaran now became a counterbalance to the

CEJISS regular military. The Pasdaran has since then been held higher than 3/2020 the regular military. In a speech, the current supreme leader of the IRI, Ali Khamenei, stated that although other organs of the IRI eventually became revolutionary, the Pasdaran was created, established and built by the revolution itself. ${ }^{14}$

\section{The aim of the Pasdaran}

The role of the Pasdaran is stated in the constitution of the IRI, article 150: 'The Islamic Revolutionary Guard Corps [...] shall continue to exist in order to carry out its role as the protector of the revolution and its achievements.' ${ }^{15}$ The Pasdaran also has its own statute which confirms the above statements. ${ }^{16}$ The constitution of the IRI, article IIO, point 6e, states that the supreme leader is the commander in chief of the Pasdaran. ${ }^{17}$

Pasdaran is today one of the most powerful institutions of the IRI with its tentacles reaching all organs of the country, not least its economy. ${ }^{18}$ Besides owning several large banks ${ }^{19}$, the Pasdaran also owns and controls a large engineering industry called the Khatam Al-Anbiya Construction Headquarters ${ }^{20}$ with more than 25000 staff, working with issues such as water, oil, gas and telecommunications. The Pasdaran likewise owns several media sources thus controlling a widespread propaganda machine. ${ }^{21}$

\section{The construction and structure of the Pasdaran}

Although some of the members of the Pasdaran, including its leadership, knew each other from Islamist camps before the fall of the Shah, some of them connected and gained strong bonds during the Iran-Iraq war, which also gave them vital military experience. After its establishment, the Pasdaran was initially run by Ayatollah Hassan Lahouti Eshkevari ${ }^{22}$, with the help of Behzad Nabavi ${ }^{23}$, Ali Shamkhani ${ }^{24}$ and Mohsen Rezaei.

The Pasdaran command since its creation can be divided into two parts: the early temporary command, which was established in direct connection to the creation of Pasdaran, and the permanent command, which was established after that the Pasdaran had fully struc- 
tured and organized themselves. Starting with the first part, the first commander of the Pasdaran was Javad Mansouri 1979-80. After him, there was a short lap before the permanent command of the Pasdaran was implemented. Since then, the Pasdaran have had five commanders; Abbas Agha Zamani (I980), Morteza Rezaei (I980-8I), Mohsen Rezaei (I98I-97), Yahya Rahim Safavi (1997-07), Mohammad Ali Jafari (2007-I9) and Hossein Salami who is the incumbent commander.

The emblem of the Pasdaran consists of a fist holding a rifle in front of a globe. Above the rifle is a verse of the Qur'an, Al-Anfal 8:6o, which translated to English states: 'Prepare Against them What Force You Can'.

The structure and force of the Pasdaran remains unknown, but it is believed that the organization has more than $\mathrm{I} 2 \mathrm{O}$ ooo members with sections in at least all large cities of Iran. ${ }^{25}$ Pasdaran consists of several branches; Pasdaran Army forces, Pasdaran Navy forces, Pasdaran Aerospace forces, the QF, the Basij, the organization for intelligence, the counterintelligence organization as well as the security organization. The organizational chart of the Pasdaran and its leadership is presented in figure I.

The navy of the regular military is responsible for the Gulf of Oman and beyond, while the Pasdaran navy forces has control over operations in the Persian Gulf. Both navies have, however, overlapping responsibilities in the vital Strait of Hormuz. As the air forces of the regular military controls the combat aircrafts of the IRI, the Pasdaran aerospace forces mostly focuses on the IRI's missile program. While the regular army secures and guards the borders of Iran, the Pasdaran ground forces mainly focus on questions of internal security and to organize paramilitary organizations and the Basij to combat unrest in the country. ${ }^{26}$

The Basij, officially in Farsi named Sazeman-e Basij-e Mostazafin (the Organization for Mobilization of the Oppressed) is a Khomeini-loyalist militia founded after the victory of the Islamic Revolution with voluntary members as young as I5 years old, who launched massive human-wave assaults against the Iraqis in the Iran-Iraq war. ${ }^{27}$

The organization for intelligence gathers both domestic and foreign intelligence. The counterintelligence organization is responsible for counterespionage and safeguarding the Pasdaran from infiltration. The security organization has no intelligence gathering responsibilities and works with security issues like close protection.
Qods Force in Iranian Foreign Policy 


\section{The Qods Force of the Pasdaran}

The QF was established in 1990 as a development of the Office of Islamic Liberation Movements in the Pasdaran. The Office was established shortly after the Islamic revolution and was headed by the prominent CEJISS cleric Hossein Ali Montazeri ${ }^{28}$. One of the main objectives of the Office 3/2020 was to coordinate Iran's support for different Islamic organizations like the Hezbollah.

The first commander of the QF was Ahmad Vahidi ${ }^{29}$. However, the longest serving commander of the QF was Qasem Soleimani, who ascended as the head of the QF in I998. On 3 January 2020, Soleimani was assassinated by US forces in Iraq and replaced by Esmail Gha' ani. The importance of the QF can be understood by the fact that the commander of the QF reports directly to the supreme leader, Ali Khamenei, bypassing the regular chain of command which other branches of the Pasdaran must follow, i.e. report to the commander of the Pasdaran who in turn report to the supreme leader..$^{30}$

Since its establishment, the QF has been conducting covert operations outside of Iran like terrorism, espionage, sabotage and destabilization of countries deemed to be enemies of the IRI. ${ }^{3 \mathrm{I}}$ The estimated strength of the QF is unknown and is by Iran experts and analysts put at between 5000 and 15000 operatives. ${ }^{32}$

\section{Foreign policy of the Islamic Republic of Iran}

Although Iran has been wrapped in a domestic struggle for power between the moderates and the conservatives for many years, the use of terrorism in its foreign policy has been nurtured under presidents of both camps. ${ }^{33}$ While the IRI denies any role in terror attacks it is blamed for and especially the many assassinations it is accused of against Iranian opponents in exile, Wege argues that 'Tehran does little to conceal its role in these assassinations. ${ }^{34}$ The reason for this may be that Iran does not see its actions as terrorism but rather as resistance.

Article 152 of the constitution states that 'the foreign policy of the Islamic Republic of Iran shall be based on the [...] defence of the rights of all Muslims [...] ${ }^{35}$ Although this statement is not further discussed in the different articles of the constitution, the preamble argues that the '[...] Constitution paves the way for the perpetuation of this Revolution in and outside the country [...] it tries to prepare the ground for the creation of a single world Ommat ${ }^{[36]}[\ldots]$ '. 
It is the above declarations in conjunction with Khomeini's statements on the question of the revolution, which supports the IRI mission of exporting the Islamic revolution. ${ }^{37}$ The current foreign minister of the IRI, Mohammad Javad Zarif, endorses the constitution arguing that 'Iran seeks to enhance its regional and global stature; to promote its ideals. ${ }^{3}{ }^{8}$ How much this is an expression for exporting the revolution is thus unclear.

Ardavan

Khoshnood

\section{Regional foreign policy of the Islamic Republic}

Although not Iran's creation, Iran had a decisive role in the emergence of the Lebanese Hezbollah which since the victory of the Islamic revolution has received significant financial and logistical resources as well as weapons from the Pasdaran. The Hezbollah is without doubt one of IRI`s most important achievements in its foreign policy. Hezbollah was not only a tool for the IRI to spread the Islamic revolution, but also a tool to use terrorism against enemy-states. ${ }^{39}$ The former commander of the QF, Qasem Soleimani, has stated that Iran has been present in Lebanon in supporting the Hezbollah, and that he himself was in Lebanon during the 2006 war between Israel and Hezbollah. $4^{\circ}$

One antagonist to Iran is Saudi Arabia which the IRI has tried to influence. Probably, at least to some degree, as a reaction to this, the Shia cleric Nimr Al-Nimr was executed by Saudi Arabia in January 2016, further infecting the tensions between the two states. It should, however, be noted that Al-Nimr did not have much sympathy for the IRI and vice versa as he was from the Shirazi school of the Shia faith descending from Ayatollah Mohammad Mahdi Shirazi ${ }^{4}$. As the political thought of the Shirazi school did not align well with the political system of the IRI, clerics of the Shirazi school did not fall out well with the leadership of the regime. ${ }^{42}$ However, Al-Nimr could be used by the IRI as propaganda against the Saudis. Another way the IRI tries to encounter Saudi Arabia, is through supporting the Houthis in Yemen in combating the Yemeni government which is highly supported by Saudi Arabia. ${ }^{43}$

A second country which the IRI has strained relations with is Bahrain. As the majority of the population in Bahrain are Shia Muslims, and Iran house Bahraini activists fighting the Al-Khalifa family ruling the country, Iran has often been accused of agitating the Shias against the Bahraini government. Although Iran denies any activities in supporting the Shias in Bahrain, Bahrain claims otherwise and has in reaction toward the actions of Iran, cracked down on the Shia community and revoked the citizenship of the Bahraini Shia cleric Isa Qassim. ${ }^{44}$ 
The conflicts between IRI and Bahrain, however, date back to the victory of the Islamic revolution and the unsuccessful I98I coup by the now defunct Islamic Front for the Liberation of Bahrain (IFLB). The IFLB was founded in the I970s and had the overthrow of the Al-Khal-

CEJISS ifa regime as its main objective. In I980 the IFLB declared loyalty to 3/2020 Ruhollah Khomeini, and in I98I they tried to topple the Al-Khalifa regime. The IFBL was connected to the IRI and its members also received training by the Pasdaran. ${ }^{45}$

Iran is furthermore highly active in Syria with the QF to fight the opposition to Assad. Also, the Lebanese Hezbollah, on orders from Iran, is active in Syria fighting for Assad. ${ }^{6}$ Interestingly, Iranian officials and members of the QF, initially, repeatedly denied any involvement in Syria. ${ }^{47}$ Today, however, the IRI admits that they have a military presence in Syria via the $\mathrm{QF}^{48}$, as hundreds of Iranian members of the $\mathrm{QF}$ have been confirmed killed, among them the high profiled Pasdaran commander General Hossein Hamadani ${ }^{49}$.

Iran and the QF are also active in Afghanistan. After the invasion of Afghanistan, the IRI have gained more influence in the country - notably among its Shia population, which is highly supported by the QF in discussing influence and propaganda..$^{\circ}$ It is thus not only through supporting subversions which the IRI tries to export its revolution and ideology. Diplomacy and negotiations are increasingly becoming part of the modus operandi of the Pasdaran and the QF.

As long as Saddam Hussein was in power in Iraq, Iran tried to destabilize the government of Saddam through its support to the Shia population of Iraq which makes the majority of the population of the country. After the fall of Saddam at the hands of the Americans, Iran gained more strength and is probably the most influential country in Iraq today. The Shia community in Iraq is also more supported by Iran than ever before. ${ }^{\mathrm{SI}}$ The QF continue to be active in Iraq in both supporting the Shia community as well as, according to the US, undermining Iraqi governments not acting on the wishes of Tehran..$^{2}$ Iran does not deny the fact that it has a military presence in Iraq via the QF, but claims they are only there to fight terrorism. ${ }^{33}$

\section{Islamic Republic's foreign policy in relation to Western Europe and America}

Even though the relation between the IRI and the US have been strained since the attack on the American embassy in Tehran by Khomeini loy- 
alists in I979, the IRI has had widespread diplomatic and commercial relations with the European Union (EU) and especially Western Europe (WE). ${ }^{54}$ The good relations with WE has, however, not stopped the IRI from conducting or attempting to conduct terrorist operations in those countries, including Canada, either against the interest of the host country or against Iranian dissidents living in those countries. ${ }^{55}$

Most WE countries have witnessed the killing of Iranian dissidents. More than 200 Iranian dissidents across the world, deemed by the IRI as threats to its existence, have over the years been killed or seriously injured in assassinations by operatives of the IRI employed either by the QF or the Iranian Ministry of Intelligence. ${ }^{56}$

In the post-Khomeini era, the foreign policy of the IRI has evolved as Iran now tries to gain more power and influence in different countries through its supporters, different organizations affiliated with the IRI, cultural organizations as well as mosques. ${ }^{57}$ The National IranianAmerican Council in the US is a good example of an organization functioning as a base of interest for the IRI.$^{8}$ The creation of the British based Iranian owned Press $T V^{59}$ is another sign of the policy change seen in the foreign policy of the IRI with emphasis on influence.

In discussing the US, the IRI through the QF is highly active in the country. Also, the Hezbollah is active in the US as well as Canada, as was seen in 2002 when American and Canadian law enforcements in different operations exposed criminality directly linked to Hezbollah operatives. ${ }^{60}$ Likewise, in Latin America the QF and Iran are highly active. Over the years, Iran has highly increased its presence in Latin America and doubled its embassies, with the one in Nicaragua being the largest with more than 150 employees. ${ }^{61}$

\section{The Qods Force and the foreign policy of the Islamic Republic}

The Pasdaran and its QF is deemed to have a vital and central role in the foreign policy of the IRI. ${ }^{62}$ On one hand, the Pasdaran is in control of the IRI's unconventional warfare, thus having an important role in the open and subtle threats made by the IRI towards other countries ${ }^{63}$; on the other hand, operatives and proxies of the Pasdaran throughout the world, via the QF, engage in covert operations and acts of terrorism. In using proxies in its operations, Ward states: 'Carrying on the tradition of the "hidden hand" attacks in the Gulf and the use of sympathetic militant groups to export the revolution during the I980s, the Guard and its QF have kept Iran actively involved in terrorism'. ${ }^{64}$ The 
use of proxies in different covert operations is admitted by the Pasdaran, which in a book published by the Pasdaran themselves states that the use of pro-revolutionary proxies outside of Iran is part of the doctrine of the Pasdaran. ${ }^{65}$

CEJISS

3/2020 The Qods Force in the region

Since the I980s Iran has initially through the Office of Islamic Liberation Movements and later via the QF controlled Hezbollah in Lebanon as well as different Shia militias in Iraq and other countries in the region to implement its foreign policy which is also admitted by the former commander of the $\mathrm{QF}^{66}$

As the IRI opposes the existence of Israel, it has always combatted and been an opponent of peace between Palestine and Israel, thus the foreign policy of the country has been focused in undermining any efforts to achieve peace, as seen in the support of the Pasdaran and its QF to Hamas and Islamic Jihad. ${ }^{67}$ The Pasdaran has also used its control over the IRI's missile program to threaten Israel. The commander of the Pasdaran Aerospace Forces, Amir Ali Hajizadeh, has in an interview stated that 'The reason we [The Pasdaran] designed our missiles with a range of $2000 \mathrm{~km}$ is to be able to hit our enemy the Zionist regime from a safe distance.68

Both in Afghanistan and Iraq, after the fall of the Taliban and Saddam respectively, Iran's foreign policy has been focused on gaining influence in the two countries. While in Afghanistan the IRI acts through diplomacy and propaganda, the QF is highly active in Iraq to gain more power and influence by supporting Shia militias. Iraq is of such importance for Iran that the former commander of the QF, Soleimani, himself, has been in Iraq directing diverse military operations. ${ }^{69}$ Most of these operations have been conducted against ISIS, but the Americans have also been targeted. In the beginning of 2007, QF operatives dressed as American troops attacked the Provisional Joint Coordination Center in Karbala, killing five American soldiers and kidnapping four who later were found murdered. $7^{\circ}$

Today, the QF is most active in implementing the foreign policy of the IRI in Syria, in defending Bashar Al-Assad. ${ }^{11}$ The survival of Assad is of great importance for the IRI, which cannot afford to lose an ally in the region. Syria is also of strategic importance for the IRI. The former deputy commander of the Pasdaran and now the current commander of the Pasdaran, Hossein Salami, said in an interview that Syria is im- 
portant in order to have a continuous interconnection between Iran, Syria, Lebanon and Palestine. Salami stated that losing Syria would mean that Iran's connection to Lebanon and Palestine would be lost, and Iran would not be able to fight the enemies of Islam, being the Israelis. ${ }^{22}$

Ardavan

Another way the QF tries to influence the region and at the same time strengthen its own position, is by persuading the diplomatic core of the IRI to appoint QF officials as diplomats and not least ambassadors. Since Iraq is of significant importance for the IRI and in particular the QF which is highly active in the country, the current Iranian ambassador to Iraq is a former senior QF official - Brigadier General Iraj Mesdaghi. The first commander of the Pasdaran, Javad Mansouri, stated in an interview that many Iranian diplomats in the region are members of the QF. In a controversial statement, Mansouri also exposed Abbas Araghchi to be a member of the QF. ${ }^{73}$ Araghchi is a career diplomat and Iran's chief nuclear negotiator. This clearly illuminates that the Pasdaran and its QF do not only use irregular warfare in order to influence and strength its power, but diplomatic channels as well.

Another example is the former commander of the QF, Soleimani, and how he has been part of extra-territorial negotiations and thus been acting as a pseudo minister of foreign affairs. Soleimani had a prominent role in negotiating between different fractions in both Iraq and Syria, and he advised the Shiite establishment in Iraq on how to negotiate with the US and the UK. ${ }^{74}$ Soleimani had also a significant role in convincing the Russians to engage in Syria and deploy their militaries in the country in support of Assad..$^{75}$ The role of Soleimani as Iran's pseudo minister of foreign affairs is much more different than the role of Mohammad Javad Zarif as the de jure Iranian minister of foreign affairs. The Pasdaran and the commander of the QF answer directly to the supreme leader, which is why he is not required to have any presidential nor parliamentary endorsement. Soleimani has thus had free hands in acting on direct orders and on behalf of the supreme leader without being exposed for internal political conflicts and disputes.

The Qods Force in the Western Europe and the American continent In the I980s and the I990s, the world witnessed hundreds of assassinations and assassination attempts against Iranian dissidents, particularly in Western Europe. Even though most of these assassinations 
remain unsolved, they have by different governments, intelligence services and organizations been attributed to the IRI. ${ }^{76}$ There are, however, few known assassinations of Iranian dissidents since May 1996. It is unclear why these assassinations have decreased, but the

CEJISS reason is probably twofold; on one hand it is difficult to conduct a co$3 / 2020$ vert operation in another country, and on the other hand, instead of conducting assassinations, which in turn would heavily affect the relationship of the IRI with the countries the assassinations are taking place in, the IRI both through its Ministry of Intelligence as well as the QF have instead been engaging in widespread espionage against Iranian dissidents and other targets of interest as have been reported by several countries. ${ }^{77}$

The QF has also, fully in accordance with the foreign policy of the IRI, gained large influences in Latin America and is highly active in the area. The fact that Hezbollah has also been increasing their presence in these countries has concerned both the Americans and the Israelis, which believe that their interests in these countries may be threatened..$^{7}$

\section{Islamic Republic's use of terrorism}

As the French in the I980s sold fighter jets to Iraq and gave a safe haven to opponents of the IRI, Iran engaged in several acts of terrorism against France. French government personnel were attacked, French citizens were kidnapped and held hostages in Lebanon and several bomb attacks at the hands of the Hezbollah shook Paris. ${ }^{79}$ Even though Iran denies any role in these terrorist attacks, a court in France in the I99os convicted Fouad Ali Saleh to life in prison because of his role in the bombings in Paris. Saleh, a Tunisian born in France, had studied in Iran and been recruited by the Lebanese Hezbollah to conduct the attacks in Paris. ${ }^{80}$ Some bomb attacks in France remain unsolved, but both the police and the French intelligence point out Hezbollah and Iran as responsible for these attacks. ${ }^{81}$ Although Iran's footprints are seen in these attacks carried out by the Hezbollah, there is no clear evidence of which role, if any, the QF has had. However, since Hezbollah is the 'primary terrorist proxy' of the QF, it is highly likely that the QF was very much involved in these attacks. ${ }^{82}$

In I994, operatives of the QF and members of the Lebanese Hezbollah bombed a Jewish community center in Argentina, the ArgentineIsraeli Mutual Association, AMIA. Two years earlier the Israeli embassy 
in Argentina was bombed, allegedly by the Iranian Ministry of Intelligence and QF operatives. ${ }^{83}$ Even though Iran denies any role in the AMIA bombing, not only has the Argentine prosecutor Alberto Nis$\operatorname{man}^{84}$ connected Iran and the QF to the bombing ${ }^{85}$, but the Argentinians have also provided sufficient evidence to issue a warrant through Interpol for the arrest of five Iranians and one Lebanese national. Among the five Iranian nationals are the former commander of the Pasdaran, Mohsen Rezaei ${ }^{86}$, former commander of the QF Ahmad Vahidi $^{87}$, and former minister of intelligence, Ali Fallahian ${ }^{88}$.

Another act of terrorism in which Iran has been convicted for in a court is the Khobar tower bombing in Saudi Arabia in 1996, where more than 500 individuals were killed and injured. In 2006, a court in the US found Iran responsible for the attacks, despite Iran's claim to the contrary ${ }^{89}$ According to the US Department of State it was the Pasdaran - and thus the $\mathrm{QF}$ - that was responsible for placing the bomb..$^{\circ}$

Ever since the establishment of the IRI, more than I6o Iranian opponents of the IRI have been killed by the regime..$^{91}$ In discussing these assassinations, it is often difficult to know which organization that has planned and executed the assassination: The Ministry of Intelligence, the $\mathrm{QF}$ or both. There is, however, no doubt that at least one of these two organizations carry out orders of assassinations against Iranian dissidents. ${ }^{92}$

The most high-profile assassination of Iranians in exile which the QF conducted was in Berlin in 1992, when four Iranians opposed to the IRI were killed in what came to be known as the Mykonos assassination. Mykonos was the restaurant the opponents had gathered in for a meeting when they were fired upon. The operation had been planned by a veteran member of the Pasdaran living in Germany and then conducted by both Lebanese and Iranian operatives of the QF. 93 The German Supreme Court in Berlin, on Io April I997, stated that the highest officials of the Islamic Republic of Iran had ordered the terrorist attacks. The verdict not only sentenced two terrorists to life in prison, but also stated that 'the political leaders of Iran gave the order, for the sole purpose of staying in power' and that 'the order givers and string pullers were Iranian state functionaries.'.94

Acts of terrorism where the IRI is suspected, but no verdicts have been passed, are the many bombings of US embassies in the ME ${ }^{95}$ and hundreds of assassinations and assassination attempts against Iranian dissidents all around the world..$^{6}$ 
In 20II the US accused the IRI and the QF for planning to assassinate the Ambassador of Saudi Arabia in the US. ${ }^{97}$ According to US officials, it was after that a QF operative living in the US contacted whom he believed was a member of a Latin American drug cartel (but in fact

CEJISS was an undercover informant for the Drug Enforcement Agency) to 3/2020 negotiate payment for killing the Saudi Arabian Ambassador in the US when the plot was revealed..$^{98}$ The IRI denied any involvement in plans to assassinate the Saudi ambassador. ${ }^{99}$

Terrorist operations on foreign soil in discussing Europe and the American continent, sponsored by the IRI, have been diminishing. Iran, however, still supports acts of terrorism in at least Europe. An example is seen in Germany, where a Pakistani national was convicted for espionage for the QF with the aim of killing prominent German nationals linked to Israel. ${ }^{\text {Ioo }}$

\section{Discussion}

The IRI today mainly focuses on propaganda, lobby organizations and espionage to control and influence Iranian dissidents as well as other countries. ${ }^{\text {Ior }}$ Recently, Mahmoud Alavi, the IRI's minister of intelligence, stated in an aired interview that the IRI has followers all over the world and that these individuals are loyal to the Islamic revolution and work without pay as a lobby for the IRI. ${ }^{102}$

It is important to point out that even though there is no proof of the IRI for the last decades to be involved in any assassinations or assassination attempts in the US and the WE, it is not because of the lack of will. In late March 2017, 3I-year old Mustufa Haidar Syed-Naqfi from Pakistan was convicted by a court in Berlin for spying for Iran and the QF. The court stated that Syed-Naqfi had gathered information on prominent individuals with connection to Israel, which would be targeted by the QF. ${ }^{103}$ That the IRI has turned to propaganda and espionage therefore does not mean that the notion of terrorism has been abandoned.

In discussing the US, the IRI through QF has mainly been active against American interests in the ME and in Latin America. Since 2003 when US forces invaded Iraq and overthrew Saddam, Iran has grown stronger. Saddam was an archenemy of the IRI after the eight-year long war between the two countries. In overthrowing Saddam, the Bush administration did the IRI a favor and contributed to the growing strength of the IRI, which today has an active foreign policy in the re- 
gion. The supreme leader of Iran has stated that the QF has an important part in creating Hezbollah cells all around the world ${ }^{104}$, and with Saddam gone, the IRI can now much more easily and more effectively act upon this wish. The IRI does not hide the fact that the QF is highly active in the region. ${ }^{105}$

Ardavan

Although more than 30 years have passed since the above statement of the supreme leader of Iran, Iran's foreign policy in supporting Hezbollah and different Islamic militias in the world intensely shows that this statement is valid even today.

The IRI considers Israel and Saudi Arabia its foremost enemies in the region ${ }^{\mathrm{I0}}$, which is reflected in the foreign policy of the IRI that supports different organizations, among them terrorist organizations, with the goal of destabilizing these countries and other countries deemed to be an antagonist to the Islamic regime in Iran. ${ }^{107}$ In doing so, the foreign policy of the IRI is highly nonsectarian and in full accordance with the article I52 of the IRI's constitution and its preamble. This is, for example, seen in the IRI's support to the Sunni Islamic Jihad Movement of Palestine and Hamas. The IRI's affiliations with Al Qae$d a$, not least after the invasion of Afghanistan in which high-ranking members of Al Qaeda fled to Iran, is another example of Iran's nonsectarian support for terrorism. ${ }^{108}$

It can be summarized that Iran's actions in the region are to gain influence and export its revolution and ideology abroad. In this quest, the IRI uses terrorism or propaganda. The former is not done directly by Iranian operatives, but rather by local militias trained or supported by the QF. In discussing the use of propaganda, the IRI are only able to do that in countries in which its operatives can move somewhat freely (Iraq, Afghanistan and Syria). In these countries, the use of violence and force are only used when encountered with antagonism.

The main aim of the IRI is to guarantee regime survival. Islam and the constitution of the IRI are what legitimize the regime -- any harm to these, the idea of the state, would mean a direct threat to regime survival. The IRI can therefore not step back from its Islamic character and identity. In discussing the idea of the state, the notion of export of the Islamic revolution becomes more clear and vivid. ${ }^{109}$ Recently, the representative of Khamenei in the Pasdaran, Ali Saeidi Shahroudi, stated that the Islamic revolution must be used in order to spread Islam to the world. ${ }^{\text {IIo }}$ Also, Khamenei's representative in the QF, Ali Shirazi, has recently stated that the export of the revolution to other countries is 
the beginning of a new era in international affairs. ${ }^{\text {III }}$ In February 20I7, a senior advisor to the supreme leader, Ali Akbar Velayati ${ }^{112}$, stated in a speech that the Palestinian intifada is one of the clearest measures with respect to Iran's export of the revolution. ${ }^{\mathrm{II}}{ }^{3}$

CEJISS The Pasdaran and its QF have been an essential part of the IRI's tool 3/2020 to not only export the revolution, but also engage in covert operations and acts of terrorism in order to fight the enemies of the IRI. However, the IRI has to some degree changed its foreign policy from only focusing on terrorism, to now trying to influence different countries in other ways, which is also clearly stated by the IRI's current minister of foreign affairs that discusses economy, culture and technology as tools of influence. ${ }^{\mathrm{II} 4}$ This, to some parts, explains why the IRI has changed its modus operandi to espionage, propaganda and lobbying in order to gain influence. The unique role of Qasem Soleimani acting as a pseudo minister of foreign affairs and engaging in diplomatic talks, is yet a sign of the above.

In discussing the support for the IRI, the physical base of the regime, it is important to divide the supporters into two parts; the people residing in Iran, and the Muslim people of the world, foremost the Shias. For the IRI, the trust and faith of both groups are vital. The Iranian people is of importance in order to safeguard the regime. Not being able to control the people either by using violence or force, as seen after the presidential election of 2009, or by keeping its legitimacy, may contribute to the fall of the IRI. Regarding Muslims from other countries, their support is vital for the IRI since they are used by the regime in different covert operations through organizations like the Lebanese Hezbollah, the Saudi Hezbollah, the Kataib Hezbollah in Iraq etc. ${ }^{\text {II }}$ To trust these groups, the IRI must ensure that they are supported financially, logistically and militarily. Without their support and loyalty, the IRI will not be able to influence other countries.

\section{Implications for the future}

When Khomeini after I4 years in exile returned to Iran, the Canadian-American journalist Peter Jennings, who sat with Khomeini in the Air France plane flying to Iran, asked Khomeini how he felt now that he was to see Iran again. Khomeini answered 'nothing'. Khomeini's translator and close aid, Ghotbzadeh, himself being highly surprised by Khomeini's answer, asked Khomeini, 'nothing?', to which Khomeini again answered, 'I don't feel a thing. ${ }^{\text {II6 }}$ This filmed interview was, of 
course, never aired in Iran, but is today widely spread in the country and notably in social media. ${ }^{\mathrm{II7}}$ Although this statement of Khomeini is today mocked and discussed by Iranians to be a clear sign that Khomeini never cared about Iran, the reality is more complex. Khomeini's answer was fully in conjunction with his Islamic ideology and I would argue that it also laid the ground for the concept of a borderless Islamic world. For Khomeini, Islam and Islamism, an internationalist ideology, was the important issue. This is significant to understand in order to grasp Khomeini's ideology, the ideology of the IRI today and its future actions.

In the region, the IRI considers itself a great and large power. Iran's ambitions of controlling the ME are highly alive, not least since the fall of Saddam. The fact that the Saudis tried to cooperate with the Israelis to harm the IRI is a clear sign of the concern which these countries have over Iran's ambitions in the region. ${ }^{\text {II8 }}$ The foreign policy of the IRI will continue to be aggressive and hostile in the region. The role of the Pasdaran and especially its QF will, in all likelihood, also continue to grow, as Iran continues to aspire for more influence in the region. In this matter, the role of terrorism and the use of violence will be highly vivid. As the Pasdaran is one the most important institutional expressions of the state, and as the ME, at least now, continues to be unstable, the physical base of the state demands actions from the Pasdaran, as is seen in the case of Syria.

Looking at the WE and the American continent, the IRI will probably mostly focus its acts of terrorism in Latin America and Eastern Europe. Only to a minor degree will the IRI focus on terrorism in WE, and then possibly target Israelis and Israeli interests ${ }^{\mathrm{II}}$, as well as important Iranian dissidents. American interests will most likely be targeted by the IRI in the ME and Latin America.

One factor, however, should be remembered, and that is if the IRI feels threatened, it will not take any considerations of diplomatic relations nor cost of life, and will use terrorism to save itself. The blockage or disruption of the Strait of Hormuz, which is a matter of national security for the US ${ }^{\mathrm{r} 20}$, is without doubt a strategy the IRI will use if threatened. Hostage taking of ships in the Persian Gulf as well as foreigners in Iran will be other strategies that have been and will be used.

For Khomeini, as for the current supreme leader, Khamenei, violence and threats were and are the way to counter antagonism to the IRI. ${ }^{\mathrm{III}}$ As long as Khamenei is the supreme leader of the country, the foreign 
policy of the IRI will probably not change for the better. Khamenei has led Iran for more than two decades and is the symbol of resistance for many in the Islamic world. Khamenei has developed the foreign policy of the country in accordance with the constitution of the IRI, thus it

CEJISS cannot easily be abandoned, not least because of the obligations the 3/2020 IRI has to its physical base and the importance of remaining loyal to its idea of the state. To discuss changes in the foreign policy of the IRI from a perspective of a conservative president or moderate president in Iran is therefore wrong, since the president on one hand acts on orders from the supreme leader, and on the other hand is himself fully loyal to the principles of the Islamic revolution and the ideology of the IRI. Over the years, Iran has had both conservative and moderate presidents without any significant differences in their respective foreign policies and their use of the QF in order to implement the foreign policy of the country. There is no doubt that the foreign policy of the IRI to some degree has softened in the post-Khomeini era, however, the IRI continues to dominate the international arena with its support to terrorism, espionage and other ways to destabilize countries deemed to be enemies of the revolution.

As long as Khamenei continues to rule Iran, and as long as the establishment of the country consists of individuals themselves being part of the revolution and loyal to the IRI, no vital changes in the foreign policy of the IRI will be seen, and Iran will continue its hostile foreign policy. Professor Misagh Parsa in his recent book on Democracy in Iran, states 'Taken together, these variables help determine whether the likely route to democratization will proceed through reform or revolution. The variables suggest that it is highly unlikely for Iran to democratize through reform [...]. ${ }^{122}$ If this statement by professor Parsa is valid, and the people of Iran would come to the same conclusion, the use of terrorism both inside Iran and outside by operatives of the Ministry of Intelligence, the Pasdaran and the QF respectively, will be a great threat in both discussing human rights and questions concerning national and international security. 
Figure I. The structure of the Pasdaran and its leadership.

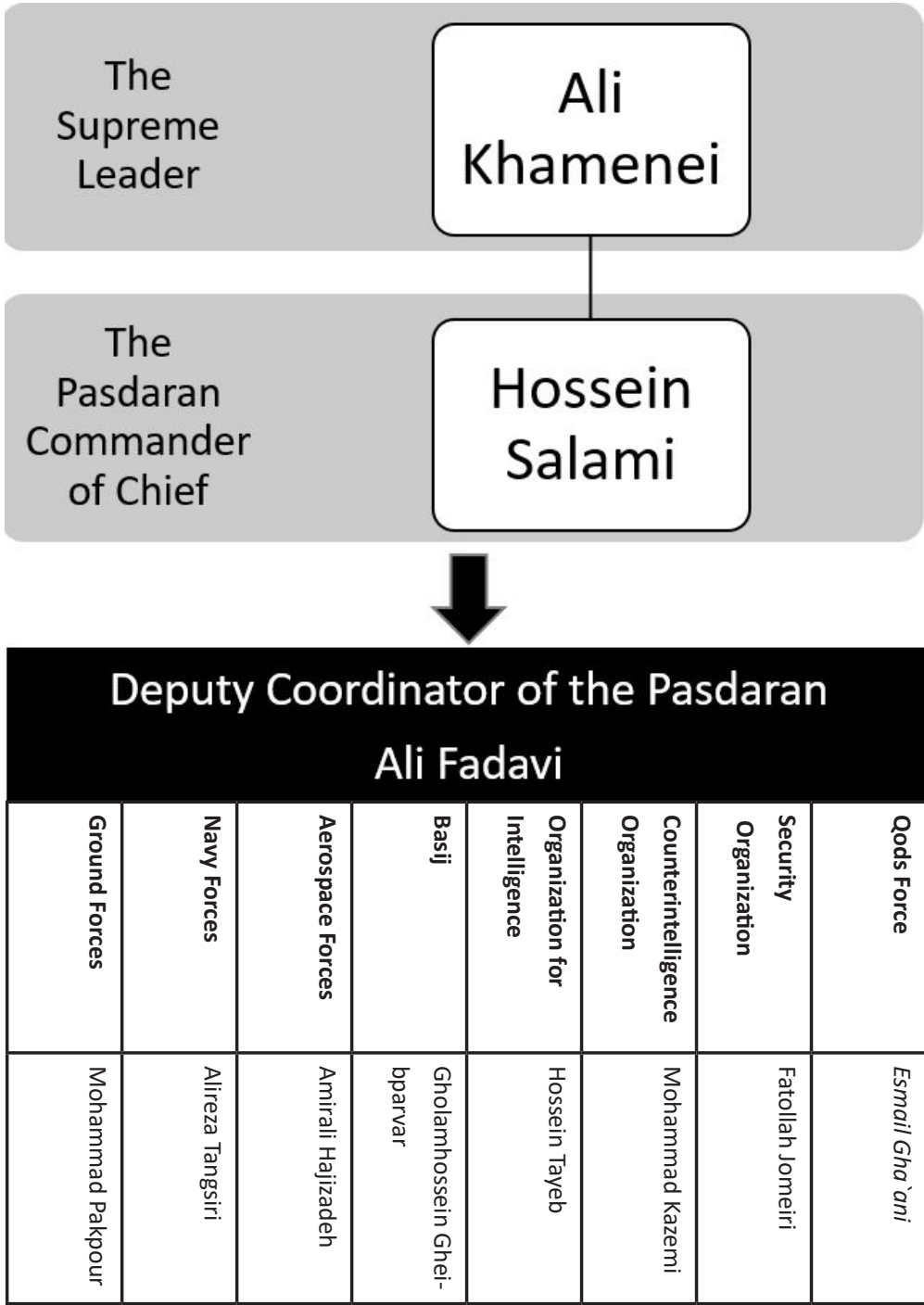

$\approx$

ARDAVAN KHOSHNOOD is affiliated with Department of Clinical Sciences Lund, Lund University, and can be reached at ardavan.khoshnood@med.lu.se. 


\section{Endnotes}

I Masserat Amir-Ebrahimi (2009), 'Weblogistan: The emergence of a new public sphere in Iran,' in Seteney Shami (ed.) Publics, Politics and Participation: Locating the Public Sphere in the Middle East and North Africa, New York: Social Science Research Council.

CEJISS 2 Sepehr Zabih (I982), 'Aspects of Terrorism in Iran,' Annals of the American 3/2020 Academy of Political and Social Science 463, pp. 84-94; Magnus Ranstorp (I996), 'Terrorism in the Name of Religion, 'Journal of International Affairs 50(I), pp. 4I-62; Edgar O’balance (I997), Islamic fundamentalist terrorism, 1979-95: The Iranian Connection, London: Palgrave Macmillan; Michael Jenkins (200I), 'Terrorism and beyond: a 2Ist century perspective,' Studies in Conflict and Terrorism, 24, pp. 32I-327.

3 The full name of the organization is Sepah-e Pasdaran-e Enghelab-e Eslami, shortened Pasdaran, meaning "Guards". In English, the organization is named Islamic Revolutionary Guard Corps shortened IRGC.

4 Qods is the Arabic name for Jerusalem.

5 Justin Jalil (2015), 'Report: Hamas leader met with top Iran commander,' Times of Israel, I7 February, available at: <https://www.timesofisrael. com/report-hamas-leader-met-with-top-iran-commander/> (accessed I7 April 2020); Yossi Melman (2015), 'Iran's Al Quds Force Builds Forward Command Near Israeli Border, But War Isn't on the Horizon,' The Jerusalem Post, I7 August, available at: <https://www.jpost.com/arabisraeli-conflict/analysis-al-qaida-and-iranian-terror-are-on-the-borderbut-war-headlines-are-a-stretch-4I234I> (accessed I7 April 2020); Times of Israel (2016), 'Iranian commander: We can destroy Israel in under 8 minutes',' Times of Israel, 22 May, available at: <https://www.timesofisrael. com/iranian-commander-we-can-destroy-israel-in-under-8-minutes/<

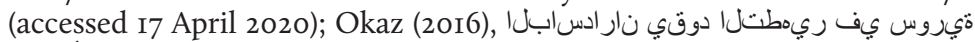

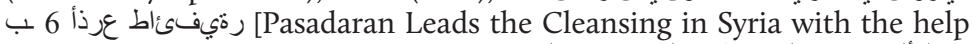

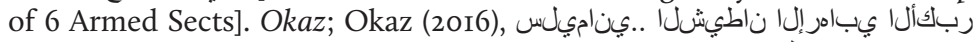

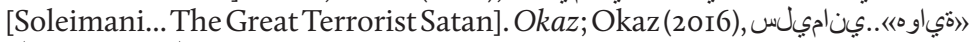
[Soleimanis Hobby is Blood and to be the Slander of History]. Okaz; Babak Dehghanipisheh and Bozorgmehr Sharafedin (2016), 'As Cold War with Saudi sharpens, Iran's Guards deliver warning,' Reuters, 5 January, available at: <https://www.reuters.com/article/us-saudi-iranguards/as-cold-war-with-saudi-sharpens-irans-guards-deliver-warningidUSKBNoUJiPX20i6oro5 > (accessed I7 April 2020); Maayan Groisman (2016), 'Commander of Elite Iranian Quds Force Meets Secretly with Hamas Delegation,' The Jerusalem Post, I7 March, available at: <https:// www.jpost.com/middle-east/commander-of-elite-iranian-quds-forcemeets-secretly-with-hamas-delegation-448286> (accessed i9 April 2020).

6 Brian Stewart (2012), 'Did intelligence fears prompt Canada to cut Iran ties?,' CBC News, II September, available at: <https://www.cbc.ca/news/ world/did-intelligence-fears-prompt-canada-to-cut-iran-ties-I.II29055> (accessed I7 April 2020); Dave Burke (2016), 'New terror alert as Iran's elite Revolutionary Guard says it is sending fighters to infiltrate US and Europe,' Mail Online, 2 November, available at: <https://www. dailymail.co.uk/news/article-38992I4/New-terror-alert-Iran-s-eliteRevolutionary-Guard-says-sending-fighters-infiltrate-Europe.html> (accessed I7 April 2020); AP (2017), 'Pakistani sentenced to prison in 
Germany for spying for Iran, 'AP News, 28 March, available at: <https:// apnews.com/29If2do792db4Ib58Ifb46dirfc2485b (accessed 30 April 2020); Rebecca Staudenmaier (2017), 'Report: Pakistani accused of spying on German politician for Iran,' Deutche Welle, 7 January, availe at: <https:// www.dw.com/en/report-pakistani-accused-of-spying-on-germanpolitician-for-iran/a-37044407> (accessed 26 April 2020); Die Zeit (2017), 'Iranischer Agent spähte SPD-Politiker aus [Iranian Agent Spied on SPDpolitician],' Die Zeit, 6 january, available at: <https://www.zeit.de/politik/ deutschland/20I7-or/spionage-agent-iran-reinhold-robbe-israel-bezug> (accessed 26 April 2020).

7 Alberto Nisman and Marcelo Martinez Burgos (2006), Office of criminal investigations: AMIA CASE, Buenos Aires: Investigations Unit of the Office of the Attorney General; Stewart (2012); Burke (2016).

8 Michael Pompeo (2019), In the Matter of the Designation of the Islamic Revolutionary Guard Corps (and Other Aliases) as a Foreign Terrorist Organization, Federal Register 84, I5278.

9 Youhanna Najdi and Mohd Azhari Bin Abdul Karim (2012), 'The Role of the Islamic Revolutionary Guards Corps (IRGC) and the Future of Democracy in Iran: Will Oil Income Influence the Process?,' Democracy and Security, 8(I), pp. 72-89.

Io Pierre Razoux (2015), The Iran-Iraq War, Cambridg: Harvard University Press.

II Emanuele Ottolenghi (20I4), The Pasdaran: Inside Iran's Islamic Revolutionary Guard Corps, Washington DC: FDD Press.

I2 The operation was planned by both members of the army and civilians. However, the most active members were from the air force who had planned to bomb the residence of Khomeini, while other members of the group would take over important organs of the government like the TV and radio. The operation was, however, uncovered and hundreds executed, the youngest a boy aged $\mathrm{I} 7$.

I3 Mahan Abedin (20II), 'Iran's Revolutionary Guards: Ideological But Not Praetorian,' Strategic Analysis, 35(3), pp. 38I-385.

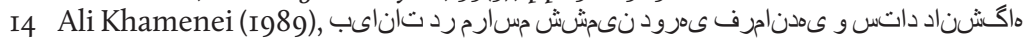
[Statement on the Sixth Term of the Graduation of the Commanders of the Imam Hussein (AS) University], Khamenei.ir, available at: <http://farsi.khamenei.ir/speech-content?id=IIO62> (Accessed or April 2020).

I5 Islamic Republic of Iran (I989), 'The Constitution of the Islamic Republic of Iran,' Islamic Consultative Assembly, available at: <http://en.parliran. $\mathrm{ir} / /$ UploadedData/89/Contents/635996064834543008.pdf> (Accessed 3I August 2020).

I6 Islamic Parliament Research Center of the Islamic Republic of Iran

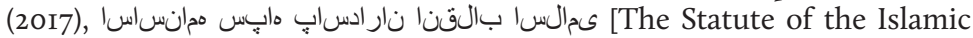
Revolutionary Guard Corps], Islamic Parliament Research Center of the Islamic Republic of Iran, available at: <http://rc.majlis.ir/fa/law/show/90595> (Accessed I7 March 2017).

I7 Islamic Republic of Iran (I989).

I8 Ali Alfoneh (2010), 'All the guard's men: Iran's silent revolution', World Affairs, I73(3), pp. 73-79; Saeed Golkar (2012), 'Organization of the oppressed or organization for oppressing: analysing the role of the Basij Militia of Iran', Politics, Religion \& Ideology, I3(4), pp. 455-47I; Mahtab Alam

\section{Qods Force in} Iranian Foreign Policy 
Rizvi (20I2), 'Evaluating the Political and Economic Role of the IRGC', Strategic Analysis, 36(4), pp. 584-596.

I9 Some of the banks are Bank-e Sepah, Bank-e Ansar and Bank-e Tosey-e Taavon.

20 Khatam Al-Anbiya is an Arabic word meaning Seal of the Prophets.

CEJISS 2I Some of the more known media sources are Sepah News, Sobhe Sadegh and Basij News Agency.

3/2020 22 Ayatollah Lahouti Eshkevari was later arrested by the IRI and suspiciously died in the notorious Evin prison (Morad Veysi (20I0), كوكشم كَرم تى نسو ا رد ىتوهال مللاتىآ [The story of Ayatollah Lahouti's Suspicious Death in Evin], Radio Farda, 29 October, available at: < https://www.radiofarda. com/a/f2_Iran_post_revolution_Lahooti_Ayatollah_death_suspicious_ strechnin_poisoned/2204740.html > (accessed I2 May 2020 )).

23 Behzad Nabavi was arrested in 2009 and sentenced to several years in prison for threatening national security (BBC (20I0), Iran jails opposition leader Behzad Nabavi, $B B C$, 9 February, available at: <http://news.bbc. co.uk/2/hi/middle_east/85070I6.stm > (Accessed 31 August 2020)).

24 Ali Shamkhani was previously the commander of the Pasdaran's navy branch and became later the commander of the navy of the regular military. Today he holds the top position of the secretary of the Supreme National Security Council.

25 Frederic Wehrey, Jerrold D. Green, Brian Nichiporuk, Alireza Nader, Lydia Hansell, Rasool Nafisi, S. R. Bohandy (2009), The rise of the Pasdaran: Assessing the domestic roles of Iran's Islamic Revolutionary Guards Corps, California: Rand Corporation.

26 Islamic Parliament Research Center of the Islamic Republic of Iran (2017).

27 Francois Géré (2007), 'Suicide Operations: Between War and Terrorism', in Gérard Chaliand and Arnaud Blin (eds.) The History of Terrorism: From Antiquity to Al Qaeda, California: University of California Press; Williamson Murray and Kevin Woods (20I4), The Iran-Iraq War - A Military and Strategic History, Cambridge: Cambridge University Press.

28 Montazeri was for a long time considered Khomeini's heir. After a dispute with Khomeini, however, Montazeri lost his position. After Khomeini's death, Montazeri had continued conflicts with the new appointed Supreme Leader, Ali Khamenei. Montazeri was therefore placed in house arrest for several years.

29 Ahmad Vahidi became the Minister of Defense of the IRI during the presidency of Mahmoud Ahmadinejad. Vahidi is since 2007 wanted by Argentine via the Interpol for charges of aggravated murder and damages (Interpol (20I7a), Vahidi, Ahmad: Wanted by Argentina, Interpol, available at: <https://www.interpol.int/How-we-work/Notices/View-RedNotices\#-49957> (Accessed 3I August 2020)).

30 William Fulton (2013), The IRGC Command Network - Formal Structures and Informal Influence, Washington: American Enterprise Institute's Critical Threats Project.

3I Carl Anthony Wege (I997), 'Iranian intelligence organizations,' International Journal of Intelligence and Counter Intelligence, Io(3), pp. 287298; Carl Anthony Wege (2010), 'The Hizballah Security Apparatus,' Perspectives on Terrorism, 2(7), pp. II-I7; Udit Banerjea (2015), 'Revolutionary Intelligence: The Expanding Intelligence Role of the Iranian Revolutionary Guard Corps,' Journal of Strategic Security, 8(3), pp. 92-Io6; Michael 
Wigginton, Robert Burton, Carl Jensen, David McElreath, Stephen Mallory, and Daniel Doss (2015), 'Al-Qods Force: Iran's weapon of choice to export terrorism,' Journal of Policing, Intelligence and Counter Terrorism, Io(2), pp. I53-I65.

32 Ben Smith (2007), The Quds Force of the Iranian Revolutionary Guard, London: The House of Commons Library; Anthony H. Cordesman and Martin Kleiber (2007), Iran's military forces and warfighting capabilities: the threat in the Northern Gulf, Washington: Center for Strategic and International Studies; Steven O'hern (20I2), Iran's revolutionary guard: the threat that grows while America sleeps, Virginia: Potomac Books; Ilan Berman (20I6), Iran's deadly ambition: The Islamic Republic's quest for global power, New York: Encounter Books.

33 Walter Laqueur (1996), 'Postmodern terrorism,' Foreign Affairs, 75, 2436; Ladan Boroumand and Roya Boroumand (2002), 'Terror, Islam, and democracy, ' Journal of Democracy, I3(2), 5-20; Iran Human Rights Documentation Center (2007), Murder at Mykonos: Anatomy of a Political Assassination, Connecticut: Iran Human Rights Documentation Center; Iran Human Rights Documentation Center (2008), No Safe Haven: Iran's Global Assassination Campaign, Connecticut: Iran Human Rights Documentation Center; Iran Human Rights Documentation Center (20II), Condemned by Law: Assassination of Political Dissidents Abroad, Connecticut: Iran Human Rights Documentation Center.

34 Wege (1997).

35 Islamic Republic of Iran (I989).

36 The constitution in a footnote translates ommat to nation.

37 R. K. Ramazani (1989), 'Iran's Foreign Policy: Contending Orientations,' Middle East Journal, 43(2), pp. 202-2I7.

38 Mohammad Javad Zarif (20I4), Iran is committed to a peaceful nuclear program, Washington Post, I3 June, available at: <https:// www.washingtonpost.com/opinions/mohammad-javad-zarif-iran-iscommitted-to-a-peaceful-nuclear-program/20I4/o6/I3/49Ifc982-fi97IIe3-bf76-447a5df64IIf_story.html> (accessed 4 April 2020).

39 Judith Palmer Harik (2005), Hezbollah: The changing face of terrorism, New York: IB Tauris; Mona Harb \& Reinoud Leenders (2005), ' Know thy enemy: Hizbullah,'terrorism'and the politics of perception,' Third World Quarterly, 26(I), pp. I73-I97; Marc DeVore (2012), 'Exploring the Iran-Hezbollah relationship: A case study of how state sponsorship affects terrorist group decision-making,' Perspectives on Terrorism, 6(4-5), pp. 85-107; Shahram Akbarzadeh (2016), 'Why does Iran need Hizbullah?,' The Muslim World, Io6(I), pp. I27-I40.

40 Islamic Consultative Assembly News Agency (20I6), زاعنامىلس ر ادرس هرط [The Recollection of General Soleimani of his Common Meeting with Larijani in Attendance of the Leader], Islamic Consultative Assembly News Agency, available at: <http:// www.icana.ir/Fa/News/294723> (accessed I April 2020).

4I Shirazi (I928-200I) was a grand ayatollah. Initially he supported Khomeini in the Islamic revolution but had soon conflicts with him why he never became part of the inner circle of the regime.

42 Toby Matthiesen (20I6), The World's Most Misunderstood Martyr, Foreign Policy, 8 January, available at: <https://foreignpolicy.com/2016/or/o8/theworlds-most-misunderstood-martyr/> (accessed 23 March 2020). 
43 Jack Freeman (2009), 'The al Houthi Insurgency in the North of Yemen: An Analysis of the Shabab al Moumineen,' Studies in Conflict \& Terrorism, 32(II), pp. I0o8-IOI9; Andrew Terrill (2014), 'Iranian involvement in Yemen,' Orbis, 58(3), pp. 429-440.

44 Al-Jazeera (20I4), Bahrain accuses Iran of training rebels, Al-Jazeera, 3 january, availe at: <https://www.aljazeera.com/news/middleeast/20I4/oI/ bahrain-accuses-iran-training-rebels-20I4I3I440498I4960.html> (accessed 23 April 2020); BBC (20I6), Bahrain revokes top Shia cleric Isa Qassim's citizenship, $B B C$, available at: <http://www.bbc.com/news/ world-middle-east-36578000> (Accessed 3I August 2020).

45 Hasan Tariq Al-Hasan (20II), ' The role of Iran in the failed coup of I98I: the IFLB in Bahrain,' Middle East Journal, 65(4), pp. 603-617.

46 Geneive Abdo (20II), How Iran keeps Assad in power in Syria, Foreign Affairs, available at: <https://www.foreignaffairs.com/articles/iran/20II-o8-25/ how-iran-keeps-assad-power-syria> (accessed I8 May 2020); Mariano V. Ospina and David H. Gray (20I4), 'Syria, Iran, and Hizballah: A Strategic Alliance,' Global Security Studies, 5(I), pp. 27-36.

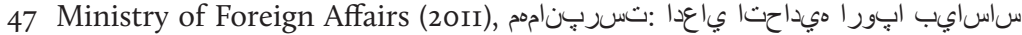
[Mehmanparast: The Claim of the European Union is Baseless and Manipulative], Ministry of Foreign Affairs, available at: <http:// $\mathrm{mfa} . \mathrm{ir} /$ index.aspx?fkeyid=\&siteid=I\&pageid=2I22\&newsview=I78I3>

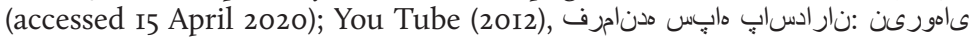
[مىروس رد هابِ سدق 200 Commander of Pasdaran: The Qods Forces in Syria], You Tube, available at: <https://youtu.be/2xo5kZBblpM > (accessed 2 April 2020); Bozorgmehr Sharafedin (2016a), Death toll among Iran's forces in Syrian war passes I,ooo, Reuters, available at: <https://www.reuters.com/ article/us-mideast-crisis-syria-iran/death-toll-among-irans-forces-insyrian-war-passes-Iooo-idUSKBNi3Hi6J> (accessed 22 April 2020).

48 Islamic Parliament Research Center of the Islamic Republic Of Iran (2016),

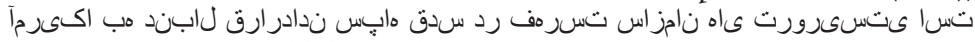
[The US is trying to Add the Pasdaran to the List of Terrorist Organizations], Islamic Parliament Research Center of the Islamic Republic of Iran, available at: http://rc.majlis.ir/fa/news/show/983639 (Accessed I April 2020).

49 Press TV (2015), Rouhani extends condolences over IRGC commander killing in Syria, Press TV, 9 October, <https://www.presstv.com/ Detail/2015/Io/o9/432643/Iranian-commander-Syria-Major-GeneralHossein-Hamedani>, available at: (accessed I April 2020); Bozorgmehr Sharafedin (20I6b), Iran's army denies direct involvement in Syria, speaks of 'volunteers, Reuters, 20 April, available at: <https://uk.reuters.com/ article/uk-mideast-crisis-syria-iran-idUKKCNoXHir)> (accessed i5 April 2020).

50 Wigginton et al. (2015).

5I Denise Natali (2017), 'Syria's Spillover on Iraq: State Resilience,' Middle East Policy, 24(I), pp. 48-6I.

52 Kenneth Katzman (20I7), Iran's Foreign and Defense Policies, Washington: Congressional Research Service; Natali (20I7).

53 Islamic Parliament of Iran (20I4), نىب ىر اوتسا دنوى" مقلح ىوقت رادرس [General Taghvi: There is a Strong Connection Between the Iranian and the Iraqi People, Islamic Parliament of Iran, available at: http://www.parliran.ir/majles/fa/Content/4_ artmajlesi/49I39-\%D8\%B3\%D8\%Bi\%D8\%AF\%D8\%A7\%D8\%Bi\%2o 


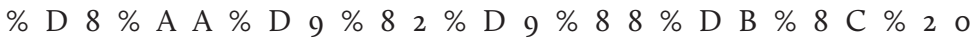

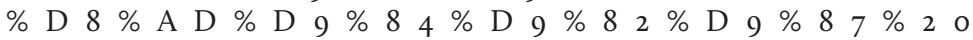
\%D 9\%BE\%DB\% 8C\%D 9\% 88\%D 9\%86\%D 8\%AF\% 2 \% D 8\%A 7\%D$8 \%$ B $3 \%$ D $8 \%$ A A \% D $9 \% 88 \%$ D $8 \%$ A $7 \%$ D $8 \%$ B I \% D B \% 8 C \% 20

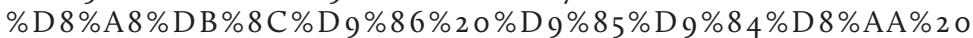

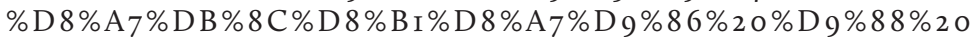

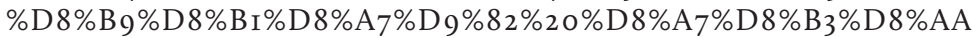
(accessed 20 April 2020); Islamic Consultative Assembly News Agency (20I6).

54 Katzman (2017).

55 Michael Reisman (I995), ' Covert Action,' Yale Journal of International Law, 20(4I9), pp. 4I9-425; Wege (1997); Dennis Pluchinsky (I997), ' The terrorism puzzle: Missing pieces and no boxcover,' Terrorism and Political Violence, 9(I), pp. 7-IO; Thomas Badey (I998), 'Defining international terrorism: A pragmatic approach,' Terrorism and Political Violence, Io(I), pp. 90-I07; Stéphane Leman-Langlois and Jean-Paul Brodeur (2005), 'Terrorism Old and New: Counterterrorism in Canada,' Police Practice and Research, 6(2), pp. I2I-I4O.

56 Pluchinsky (1997); Wege (I997); Badey (I998); Iran Human Rights Documentation Center (2007); Iran Human Rights Documentation Center (2008); Iran Human Rights Documentation Center (20II); Wigginton et al. (2015).

57 Nisman and Burgos (2006); Michael Rubin (2017), Iran's Emboldened U.S. Lobby, Commentary Magazine, 20 March, available at: <https://www. commentarymagazine.com/michael-rubin/irans-emboldened-u-s-lobbyniac/> (accessed I5 April 2020).

58 Jefrey Goldberg (2009), Trita Parsi, Lobbyist for Iran?, The Atlantic, I3 November, availabe at: <https://www.theatlantic.com/international/ archive/2009/II/trita-parsi-lobbyist-for-iran/30133/> (accessed 26 August 2020); Alex Shirazi (2015), The Shady Family Behind America's Iran Lobby. The Daily Beast, I5 September, available at: < https://www.thedailybeast. com/the-shady-family-behind-americas-iran-lobby > (accessed 26 August 2020); Adam Kredo (20I7), Former Iranian Official, Pro-Tehran Lobbyist Hosted at Obama White House Dozens of Times, The Washington Free Beacon, 23 January, availabe at: <https://freebeacon.com/national-security/ former-iranian-official-pro-tehran-lobbyist-hosted-obama-white-housedozens-times/> (accessed 26 August 2020); Rubin (2017).

59 Press TV was launched in 2007 and is owned by the IRI. President Mahmoud Ahmadinejad visited the Press TV staff on its opening ceremony (Nazila Fathi (2007), Iran expands role in media, via satellite and in English, The New York Times, 3 July, available at: <https://www.nytimes.com/2007/07/03/ world/middleeast/oziran.html $>$ (accessed 26 August 2020)).

60 Wigginton et al. (2015).

6I Cynthia J. Arnson, Haleh Esfandiari and Adam Stubits (2009), Iran in Latin America: Threat or 'Axis of Annoyance'?, Washington: Woodrow Wilson International Center for Scholars. Matthew Levitt (2013), Iranian Terrorism Under 'Moderate' Presidents, Washington: The Washington Institute for Near East Policy.

62 Zabih (I982); Kamran Taremi (2005), 'Iranian foreign policy towards occupied Iraq, 2003-05,' Middle East Policy, I2(4), 28-47; Abdo (2011); Wigginton et al. (20I5); Akbarzadeh (20I6).

\section{Qods Force in} Iranian Foreign Policy 
63 Steven R. Ward (2014), Immortal: A Military History of Iran and Its Armed Forces, Washington: Georgetown University Press; Press TV (20I6), Iran test-fires two ballistic missiles during large-scale drills, Press TV, 9 March, available at: <https://www.presstv.com/ Detail/20I6/03/09/45468I/iran-irgc-ballistic-missile) (accessed 22

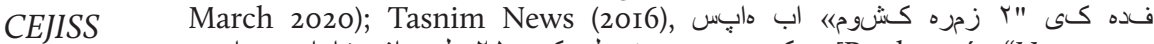
$3 / 2020$

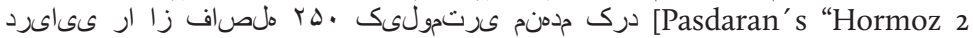
Missile" was Able to Destroy a Maritime target $250 \mathrm{~km}$ Away], Tasnim News, available at: <https://www.tasnimnews.com/fa/news/r395/r2/ I9/1350668/\%D8\%B3\%D9\%BE\%D8\%A7\%D9\%87-\%D8\%A8\%D8\%A7\%D9\%85\%D9\%88\%D8\%B4\%DA\%A9-\%D9\%87\%D8\%Bi\%D9\%85\%D8\%B22-\%DB\%8C\%DA\%A9-\%D9\%87\%D8\%AF\%D9\%8I-\%D8\%AF\%D8\%Bi\%DB \%8C\%D8\%A7\%DB\%8C\%DB\%8C-\%D8\%Br\%D8\%A7-\%D8\%A7\%D8\%B2\% D 9 \% 8 I\%D 8\%A7\% D8\%B5\%D 9\% 84\%D 9\% 8 7-250-\%DA\%A 9\%DB \% 8C \% D $\% 84 \%$ D 9\% 88\%D 9\% 85\%D 8\%AA\%D 8\%B I \% DB\% 8C-\%D$9 \% 85 \%$ D9\%86\%D9\%87\%D8\%AF\%D9\%85-\%DA\%A9\%D8\%Bi\%D8\%AF> (accessed 30 August 2020); Sam Wilkin and Bozorgmehr Sharafedin (2016), Despite Threat Of Sanctions, Iran Tests Missiles Marked With The Phrase 'Israel Must Be Wiped Out', Huffington Post, 9 March, available at: <https:// www.huffpost.com/entry/iran-missile-tests_n_56eoooace4bo86of99d73 ba5> (accessed 26 April 2020).

64 Ward (2014).

65 Mohammad Hossein Jamshidi (200I), Basis and History of Military Thought in Iran, Tehran: Islamic Revolutionary Guard Corps College of Command.

66 Islamic Consultative Assembly News Agency (2016).

67 Ward (20I4).

68 Wilkin and Sharafedin (2016).

69 Shahram Akbarzaadeh (2015), 'Iran and Daesh: the case of a reluctant Shia power,' Middle East Policy, 22(3), pp. 44-54.

70 Wigginton et al. (2015).

7I Islamic Parliament Research Center of the Islamic Republic of Iran (2016).

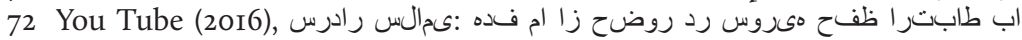
[General Salami: Our Aim of Being in Syria is to Protect our Connections with Hezballah and Palestine], You Tube, available at: <https://youtu.be/dp6hdfx8gcY> (Accessed 2 April 2020).

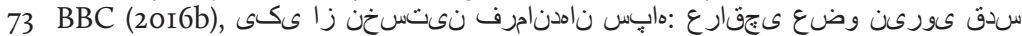
تسا [One of the first commanders of the IRGC: Araghchi is a member of the Quds Force], $B B C$, available at: <https://www.bbc.com/persian/ iran/2016/06/160615_145_mansouri_araghchi_irgc> (accessed 3I August 2020).

74 Yossi Alpher (2019), Winners and Losers in the 'Arab Spring': Profiles in Chaos, New York: Routledge.

75 Laila Bassam and Tom Perry (2015), How Iranian general plotted out Syrian assault in Moscow, Reuters, 6 October, avilable at: <https:// www.reuters.com/article/us-mideast-crisis-syria-soleimani-insigh/ how-iranian-general-plotted-out-syrian-assault-in-moscowidUSKCNoSo2BV20151006> (accessed I5 April 2020).

76 Iran Human Rights Documentation Center (2007); Iran Human Rights Documentation Center (2008); Iran Human Rights Documentation Center (20II).

77 Library of Congress (2012), Iran's Ministry of Intelligence and Security: 
A Profile, Washington: Library of Congress; Säkerhetspolisen (20I2), Främmande makt - flera fall av iakttagelser om underrättelsehot [Foreign Powers - Several Cases of Intelligence Threats], Stockholm: Säkerhetspolisen; AFP (20I7); Die Zeit (20I7).

78 The Meir Amit Intelligence and Terrorism Information Center (2012), Latin America as an Arena for Iran and Hezbollah's Terrorist, Subversive and Criminal Activities, Ramat Hasharon: The Meir Amit Intelligence and Terrorism Information Center; Matthew Levitt (2015), 'Iranian and Hezbollah Operations in South America: Then and Now,' PRISM, 5(4), pp. II9-I33.

79 Richard Bernstein (I986), The terror: Why france? Why now?, The New York Times, I9 October, available at <https://www.nytimes.com/ı986/ıo/ı9/ magazine/the-terror-why-france-why-now.html> (accessed I September 2020); Pluchinsky (1997); Murray and Woods (2014); France 24 (2016), In pictures: France and Iran's turbulent diplomatic history, France 24, available at: <https://graphics.france24.com/france-iran-relationspictures/> (accessed i8 April 2020).

80 Youssef M. Ibrahim (I990), Trial of Accused Mastermind in Bombings Begins in Paris, New York Times, 30 January, available at: <https:// www.nytimes.com/1990/or/30/world/trial-of-accused-mastermind-inbombings-begins-in-paris.html> (accessed I2 February 2020); Boroumand and Boroumand (2002).

8I Didier Bigo (I991a), 'Les attentats de i986 en France: un cas de violence transnationale et ses implications (Partie I),' Cultures \& conflits, Winter I99I; Didier Bigo (I99Ib), 'Les attentats de I986 en France (Partie 2),' Cultures \& Conflits, Winter I99I.

82 Claude Moniquet (2019), The Recent Iranian Terrorist Plots in Europe, Brussels: European Strategic Intelligence and Security Center.

83 Wigginton et al. (2015); Katzman (2017).

84 Alberto Nisman was an Argentinian prosecutor. He led the investigation of the AMIA bombing. On January 19, 2015, he was shot and killed in his residence. Nisman had reported that he was to indict the president of Argentine for conspiring with the IRI for "downplay[ing] the AMIA bombing" (Katzman (20I7)). His homicide remains unsolved.

85 Nisman and Burgos (2006).

86 Interpol (20I7b), Rezai, Mohsen: Wanted by Argentina, Interpol, available at: <https://www.interpol.int/How-we-work/Notices/View-RedNotices\#2007-49958> (accessed 3I August 2020).

87 Interpol (2017a).

88 Interpol (20I7c), Fallahijan, Ali: Wanted by Argentina, Interpol, available at: <https://www.interpol.int/How-we-work/Notices/View-RedNotices\#2006-34754> (Accessed 3I August 2020).

89 Carol Leonnig (2006), Iran Held Liable in Khobar Attack, Washington Post, 23 December, <https://www.washingtonpost.com/archive/ politics/2006/I2/23/iran-held-liable-in-khobar-attack-spanclassbankheadjudge-orders-254-million-paymentspan/6a93eae4-7eo34I67-9cf8-c3birf42di6o/> (accessed 30 August 2020).

90 US Department of State (2019), Designation of the Islamic Revolutionary Guard Corps, US Department of State, available at: <https://www.state. gov/designation-of-the-islamic-revolutionary-guard-corps/> (accessed I7 January 2020). 
9I Iran Human Rights Documentation Center (2008).

92 Iran Human Rights Documentation Center (2007); Iran Human Rights Documentation Center (2008); Iran Human Rights Documentation Center (20II).

93 Iran Human Rights Documentation Center (2007).

CEJISS 94 Mary Williams Walsh (1997), German Court Finds Iran's Leaders Ordered Slayings, Los Angeles Times, II April, available at: <https://www.latimes. com/archives/la-xpm-I997-04-II-mn-47727-story.html> (accessed I4 April 2020).

95 Houman Sadri (1998), 'Trends in the foreign policy of revolutionary Iran,' Journal of Third World Studies, I5(I), I3-37.

96 Iran Human Rights Documentation Center (2008).

97 Daniel Byman (2015), State Sponsor of Terror: The Global Threat of Iran, Washington: U.S. House of Representatives Committee on Foreign Affairs Subcommittee on Terrorism, Nonproliferation, and Trade; Katzman (20I7).

98 Wigginton et al. (2015).

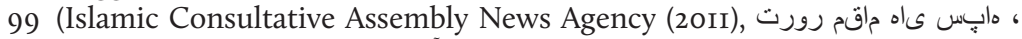
[The Terror of Pasdaran Officials Again Proves the Contradictory Behavior of America in the Fight Against Terrorism], Islamic Consultative Assembly News Agency, available at: <http://www.icana.ir/Fa/News/I8208I> (accessed I April 2020); Iran Human Rights Documentation Center (201I).

IOOAFP (2017).

IOI Fathi (2007); Goldberg (2009); Säkerhetspolisen (2012); Library of Congress (20I2); Zarif (20I4); Shirazi (20I5); AFP (20I7); Kredo (20I7); Die Zeit (20I7).

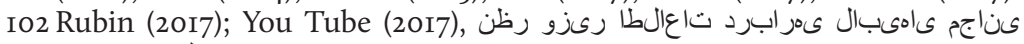
[The View of the Minister of Intelligence About the Gratis Lobbys of the Islamic Republic Abroad], You Tube, available at: $<$ https://youtu.be/bTsCNmRHAoo> (accessed 23 March 2020).

I03 AFP (2017); Staudenmaier (2017).

I04 Khamenei (I989).

I05 Islamic Parliament of Iran (2014); Islamic Parliament of Iran (2015), [وش روشكرد مشقانم ثعاب دىابن ىاهتسه عوضوم [The Nuclear Issue Should not Contribute to Conflicts in the Country], Islamic Parliament of Iran, available at: <http://www.parliran.ir/majles/fa/Content/4_ artmajlesi/52543-\%D9\%85\%D9\%88\%D8\%B6\%D9\%88\%D8\%B9\%20 \% D 9 \% $87 \%$ D $8 \%$ B 3 \% D 8\% AA \% D 9\% $87 \%$ D 8 \% A 7 \% D B \% 8 C \% 20 \% D 9 \% $86 \%$ D $8 \%$ A $8 \%$ D $8 \%$ A $7 \%$ D B \% 8 C \% D 8 \% A F \% 20 \%D8\%A8\%D8\%A7\%D8\%B9\%D8\%AB\%20\%D9\%85\%D9\%86\%D8\%A7\%D9 \%82\%D8\%B4\%D9\%87\%20\%D8\%AF\%D8\%Bı\%DA\%A9\%D8\%B4\%D9\%88\% D8\%Br\%20\%D8\%B4\%D9\%88\%D8\%AF> (accessed i April 2020).

Io6 Mohammad Javad Zarif (20I6), Why Iran is building up its defenses, Washington Post, 20 April, available at: <https://www.washingtonpost. com/opinions/zarif-what-critics-get-wrong-about-iran-and-the-nuclearagreement/20i6/04/20/7b542dee-0658-IIe6-aI2f-ea5aed7958dc_story. html $>$ (accessed I2 April 2020).

I07 Bernstein (I986); Didier (I991a); Didier (I991b); Badey (I998); Jenkins (200I); Boroumand and Boroumand (2002); Harb and Leenders (2005); Lawrence Wright (2006), The Looming Tower: Al-Qaeda and the Road to 9/II, New York: Vintage; Daniel Byman (2008), 'Iran, terrorism, and 
weapons of mass destruction,' Studies in Conflict \& Terrorism, 3I(3), pp. I69-I8I; Arnson et al. (2009); DeVore (20I2); Masoud Kazemzadeh (2013), Ayatollah Khamenei's Foreign Policy Orientation, Comparative Strategy, 32(5), pp. 443-458; Al-Jazeera, 20I4; Ospina and Gray (2014); Banerjea (20I5); Akbarzadeh (2016); France 24 (2016); Sherree DeCovny (2017), Lightning War: Outflanked by cyber-threats, can financial firms maneuver fast enough?, Virginia: CFA Institute Magazine, 28, I-3.

Io8 Philippe Migaux (2007), 'The Future of the Islamist Movement,' in: Gérard Chaliand and Arnaud Blin (eds.) The History of Terrorism: From Antiquity to Al Qaeda, California: University of California Press.

I09 Fredrik Dahl (2009), Iran cleric says "time to export the revolution", Reuters, 4 September, availabe at: <https://www.reuters.com/article/ us-iran-revolution-cleric/iran-cleric-says-time-to-export-therevolution-idUSTRE5833FV20090904> (accessed I2 March 2020);

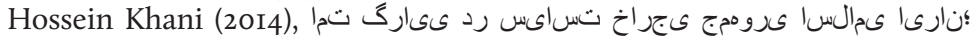

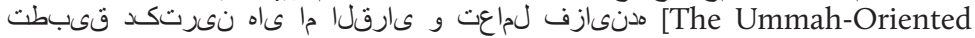
Foreign Policy of the Islamic Republic of Iran; Comparing the two Doctrines of "Umm Al-Qura "and" Increasing Engagement"], Strategic Research of Politics, 2, 9-30; Tasnim News (2016); Iranian Students News

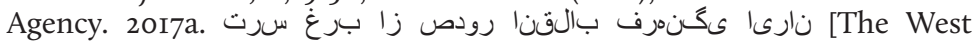
Fears the Export of Iran's Cultural Revolution]. Iranian Students News Agency, availabe at: <https://www.isna.ir/news/95III208503/\%D8\%A A\%D8\%Bi\%D8\%B3-\%D8\%BA\%D8\%Bi\%D8\%A8-\%D8\%A7\%D8\%B2\%D8\%B5\%D8\%AF\%D9\%88\%D8\%BI-\%D8\%A7\%D9\%86\%D9\%82\%D9\%84 \%D8\%A7\%D8\%A8-\%D9\%81\%D8\%Bi\%D9\%87\%D9\%86\%DA\%AF\%DB\%8C\%D8\%A7\%DB\%8C\%D8\%Bi\%D8\%A7\%D9\%86> (accessed I2 March 2020);

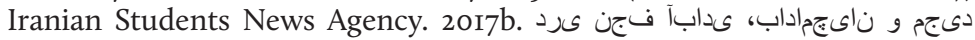
[Dorinajafabadi, Badamchian and Majid Ansari are the Speakers of the Event of I2 Bahman in Tehran]. Iranian Students News Agency, availabe at: <https:/www.isna.ir/news/ 95IIII07455/\%D8\%AF\%D8\%BI\%DB\%8C-\%D9\%86\%D8\%AC\%D9\%8I\% D $8 \%$ A 2 \% D 8\%A 8\% D 8\%A 7 \% D 8\%A F \% D B \% 8 C- \% D 8\%A 8\% D $8 \%$ A $7 \%$ D $8 \%$ A F \% D $8 \%$ A $7 \%$ D $9 \% 85 \%$ D A \% $86 \%$ D B \% 8 C \% D $8 \%$ A $7 \%$ D $9 \% 86$ - \% D $9 \% 88$ - \% D 9 \% $85 \%$ D $8 \%$ A C \% D B \% 8 C \% D 8 \% A F \% D $8 \%$ A $7 \%$ D $9 \% 86 \%$ D $8 \%$ B $5 \%$ D $8 \%$ A $7 \%$ D $8 \%$ B I \% D B \% 8 C\% D 8\%B3\% D 8\%AE\% D 9\% 86\% D 8\%B I \% 8 \% A 7\% D 9\% 86\% D 8\%A

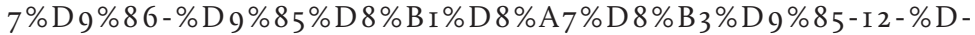
8\%A8\%D9\%87\%D9\%85\%D9\%86> (accessed I2 March 2020); Iranian Students News Agency. 20I7c. نارىا رادتقا و تدحو دامن ؛نمهب 22 ىىامى: [The 22 Bahman Demonstration: Symbol of the Unity and Authority of Iran]. Iranian Students News Agency, availabe at: <https:/www.isna.ir/ news/95II2II50I6/\%D8\%Bi\%D8\%A7\%D9\%87\%D9\%BE\%DB\%8C\%D9\% 85\%D8\%A7\%DB\%8C\%DB\%8C-22-\%D8\%A8\%D9\%87\%D9\%85\%D9\%86\%D9\%86\%D9\%85\%D8\%A7\%D8\%AF-\%D9\%88\%D8\%AD\%D8\%AF\%D8\%AA-\%D 9\% 88-\%D8\%A7\%D 9\% 82\%D8\%AA\%D 8\%AF\%D 8\%A7\%D 8\%BI-\%D8\%A7\%DB\%8C\%D8\%BI\%D8\%A7\%D9\%86> (accessed I2

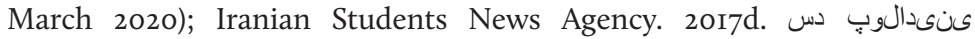
[We Have Created a Strong Barrier Agianst our Enemies]. Iranian Students News Agency, availabe at: <https://www.isna.ir/news/95II2315766/\%D8\%B3\%D8\%AF-\%D9\% BE\%D 9\% 88\%D 9\% 84\%D 8\%A7\%D8\%AF\%DB\% 8C\%D9\%86\%DB\%

\section{Qods Force in} Iranian Foreign Policy 
8C-\%D8\%AF\%D8\%BI-\%D8\%A8\%D8\%Bi\%D8\%A7\%D8\%A8\%D8\%BI\% D $8 \%$ A F \% D $8 \%$ B $4 \%$ D 9 \% $85 \%$ D $9 \% 86 \%$ D $8 \%$ A $7 \%$ D $9 \% 86-$ \% D $8 \%$ A 7 \% D B \% 8 C \% D $8 \%$ A C \% D $8 \%$ A $7 \%$ D $8 \%$ A F \%DA\%A9\%D8\%Br\%D8\%AF\%D9\%87-\%D8\%A7\%DB\%8C\%D9\%85> (accessed I2 March 2020); Iranian Students News Agency. 20I7e. نى نمكنش

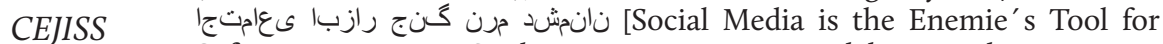
$3 / 2020$ Soft War]. Iranian Students News Agency, availabe at: <https://www. isna.ir/news/95III $409768 / \%$ D 8\%B 4\%D 8\%A8\%DA\%A9\%D 9\%87\%D9\%87\%D8\%A7\%DB\%8C-\%D8\%A7\%D8\%AC\%D8\%AA\%D9\%85\%D8 \%A7\%D8\%B9\%DB\%8C-\%D8\%A7\%D8\%A8\%D8\%B2\%D8\%A7\%D8\%BI\%D8\%AC\%D9\%86\%DA\%AF-\%D9\%86\%D8\%BI\%D9\%85-\%D8\%AF\%D 8\%B4\%D9\%85\%D9\%86\%D8\%A7\%D9\%86> (accessed I2 March 2020);

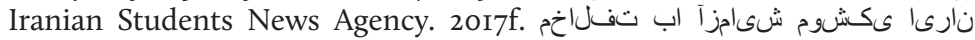
[To Oppose Iran's Missile Tests, is to Oppose the Streanghtning of the Defense of the Islamic world]. Iranian Students News Agency, availabe at: <https://www.isna. $\mathrm{ir} /$ news/95II2II 4772/\%D 9\%85\%D8\%AE\%D8\%A7\%D 9\%84\%D9\%8I \%D 8\%AA-\%D 8\%A8\%D 8\%A7-\%D 8\%A2\%D8\%B2\%D 9\% 85\%D8\%A7 \%DB\% 8C\%D8\%B4-\%D 9\%85\%D9\%88\%D8\%B4\%DA\%A9\%DB\%8C\% D 8\% A 7 \% D B \% 8 C \% D 8\% B I \% D \% A 7 \% D 9 \% 86 - \% D 9 \% 85\% D 8 \%AE\% D 8\%A 7 \% D 9\% 84 \% D 9 \% 8 I \% D 8 AA- \% D 8\%A 8\% D 8\%A 7\% D $8 \%$ A A \% D $9 \% 82 \%$ D $9 \% 88 \%$ D B \% 8 C \% D $8 \%$ A A \%D8\%A8\%D9\%86\%DB\%8C\%D9\%87-\%D8\%AF\%D9\%81\%D8\%A7\%D8\%B9\%DB\%8C-\%D8\%AC\%D9\%87\%D8\%A7\%D9\%86> (accessed I2 March 2020).

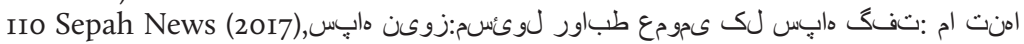

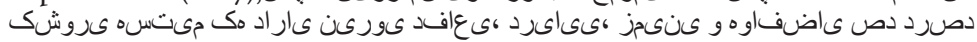

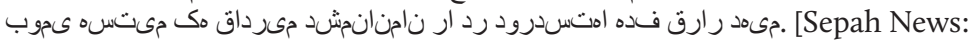
The Sepah Public Relations Official Stated: We are the Only Country Which has a One Hundred Percent Native Defense Force, Marine, Ground Force and Aerospace Which Ables us to hit our Wnemies Far Away]. Sepah News.

ابه

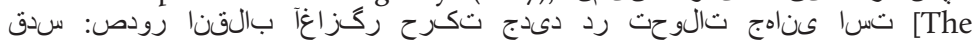
Representative of the Supreme Leader in the Qods Force: Export of the Revolution is the Beginning of a New Era in World Development], Islamic Republic News Agency, availe at: <https://www.irna.ir/news/824 24749/\%D9\%86\%D9\%85\%D8\%A7\%DB\%8C\%D9\%86\%D8\%AF\%D9\%87\%D 9\%88\%D9\%84\%DB\%8C-\%D 9\%8 I\%D9\%82\%DB\%8C\%D9\%87\%D 8\%AF\%D8\%BI-\%D8\%B3\%D9\%BE\%D8\%A7\%D9\%87-\%D9\%82\%D8\%AF\%D8\%B3-\%D8\%B5\%D8\%AF\%D9\%88\%D8\%BI-\%D8\%A7\%D 9\%86\%D9\%82\%D9\%84\%D8\%A7\%D8\%A8-\%D8\%A2\%D8\%BA\%D8\% A7\%D8\%B2\%DA\%AF\%D8\%BI-\%D8\%AD\%D8\%Br\%D9\%83\%D8\%AA\%D8\%AC\%D8\%AF\%DB\%8C\%D8\%AF-\%D8\%AF\%D8\%BI> (accessed 30 August 2020).

II2 Velayati, a physician, has served the IRI as its Minister of Health and Minister of Foreign Affairs. Since I997, Velayati is a senior advisor to the supreme leader in matters of international affairs.

II3 Iranian Students News Agency (20I7a).

II4 Zarif (20I4)

II5 Kenneth Katzman (I993), 'The Pasdaran: institutionalization of 
revolutionary armed force,' Iranian Studies, 26(3/4), 389-402; Ahmad Majidyar (2013) Saudi Arabia's forgotten Shi'ite spring, Middle Eastern Outlook, 5, pp. I-8; Wigginton et al. (2015); Natali (20I7).

II6 Elaine Sciolino (200I), Persian mirrors: The elusive face of Iran, New York: Simon and Schuster.

II7 "You Tube" is flooded with clips of the event. One can be found here: $<$ https://www.youtube.com/watch?v=ZPpB-r5mMCl>.

II8 David Sanger (20I5), Saudi Arabia and Israel Share a Common Opposition, New York Times, 4 June, available at: <https://www.nytimes. com/2015/06/05/world/middleeast/saudi-arabia-eshki-and-israel-doregold-netanyahu-share-allies-iran.html $>$ (accessed 24 August 2020).

II9 AFP (20I7).

I20 Michael T. Klare (2013), 'Energy Security,' in Paul D. Williams (ed.) Security Studies: An Introduction, New York: Routledge.

I2I Ziba Moshaver (2003), 'Revolution, Theocratic Leadership and Iran's Foreign Policy: Implications for Iran-EU Relations,' The Review of International Affairs, 3(2), pp. 283-305; Kazemzadeh (2013).

I22 Misagh Parsa (2016), Democracy in Iran: Why It Failed and How It Might Succeed. Massachusetts: Harvard University Press. 